\title{
A Diaspora in Diaspora? Russian Returnees Confront the "Homeland"
}

\author{
Hilary Pilkington and Moya Flynn
}

\begin{abstract}
The term "Russian diaspora" is used to refer to the twenty-five million ethnic Russians who in 1991 found themselves politically displaced beyond the borders of the Russian Federation and resident within newly independent states. This paper firstly reviews the problematic "classification" of these communities as a "diaspora." More specifically, by drawing on narratives of "home" and "homeland" among those Russians "forced" to return to the Russian Federation since 1991, it focuses on a central pillar of diasporic identity: the relationship to "homeland." By exploring the everyday interactions with and articulated narratives of Russia on "return," the paper argues that it is upon confrontation with "the homeland" that Russian returnees develop a sense of "otherness" from local Russian residents and a connection with other "returning Russians." The question is raised as to whether, rather than "coming home," Russians returning from the other former Soviet republics become a "diaspora in diaspora"?
\end{abstract}

\section{Résumé}

On utilise l'expression "diaspora russe » en référence aux 25 millions de Russes provenant d'ethnies différentes qui, à l'échelle politique en 1991, se sont trouvés déplacés audelà des frontières de la Russie et sont devenus des résidants d'États nouvellement indépendants. L'article s'attarde d'abord à la problématique liée à la "classification» de ces groupes en tant que "diaspora». À partir d'anecdotes se rapportant aux notions de "foyer » et de "patrie " parmi ces Russes forcés de revenir en Russie depuis 1991, l'article se penche plus particulièrement sur le pilier de l'identité de la diaspora : la relation à la "patrie ». Grâce à l'exploration des interactions quotidiennes avec la Russie et des faits racontés sur le "retour", l'article défend le point de vue suivant: c'est par la confrontation avec la "patrie " que les rapatriés russes se sensibilisent à la notion de l'" autre » vis-à-vis des résidants russes et qu'ils tissent des liens avec d'autres « rapatriés russes ». La question qui se pose alors est de savoir jusqu'à quel point les Russes qui reviennent d'autres Républiques soviétiques ne deviennent-ils pas une "diaspora dans la diaspora " plutôt que de simplement retourner chez eux.

\section{Introduction}

7 he term "Russian diaspora" refers to the twenty-five million ethnic Russians who became politically, although not physically, displaced in the wake of the collapse of the Soviet Union. ${ }^{1}$ On 1 January 1992, these Russians suddenly found themselves resident in the new geopolitical space referred to as Russia's "near abroad." The question of the applicability of the term "diaspora" to the case of Russian minorities in the former Soviet republics has received considerable attention in western academic literature since the mid $1990 \mathrm{~s},{ }^{2}$ facilitated by a wider return to the question of "diaspora" in the light of increasing concern with transnational movement and, especially from postmodernist perspectives, its implications for identity.

This paper reviews briefly the problematic "classification" of the Russian-speaking communities in the former Soviet republics as a "diaspora." More specifically, however, it pursues a central pillar of diasporic identity: the question of the relationship to "homeland." For Russianspeaking communities in the former republics "the homeland" has not been a "faraway land" generating communal myths of, and longing for, return. It has been a tangible presence - an open door - through which individuals and families choose, and re-choose, whether or not to walk. 
Indeed the peculiarly immanent nature of "the homeland" in the case of the Russian diaspora provides an excellent opportunity to explore, empirically, the centrality, or otherwise, of "homeland" in diasporic identity. This is approached in the paper by examining narratives of "home" and "homeland" among returnees to Russia, that is members of the Russian-speaking communities who were resident in the former Soviet republics upon collapse of the Soviet Union but who have since returned to Russia. ${ }^{3}$ By exploring their everyday interactions with, as well as articulated narratives of, Russia, the paper argues that it is in the very process of confrontation with "the homeland" that Russian returnees develop a sense of "otherness" from Russians resident all their lives in Russia and, post facto, a connection with "other Russians" from the former republics. The question thus is raised as to whether, rather than "coming home," Russians returning from the former republics become a "diaspora in diaspora"?

The empirical data drawn on were gathered during two distinct periods of fieldwork. During the first study, which was conducted among returnee communities between July and December 1994, data were gathered from a total of 195 Russian returnees, 144 of whom were settled in four rural settlements in the Orel region, Central Russia, the remaining fifty-one of whom were resident in the city of Ul'ianovsk in the Middle Volga region of Russia. ${ }^{4}$ The second study was conducted during the period 1997-1999 in the regions of Saratov and Samara, in the Volga region of the Russian Federation. ${ }^{5}$ Two pilot studies were conducted in Saratov region (August-September 1997, and April 1998) when data were gathered from seventeen respondents. The main period of fieldwork took place during the period June-November 1999, when data were gathered from twenty-six respondents in Saratov region and nineteen respondents in Samara region. In both studies, data were gathered primarily through semi-structured interviews (which were taped, and later fully transcribed and analyzed in Russian) and extensive field observations. Observations were made at a number of sites of migrant resettlement and the activities of migrant associations and regional migration services were monitored. In addition, basic demographic data were gathered from respondents who were also asked to provide details of sources and type of assistance received.

In both studies migrant communities were included from both urban centres (Saratov, Samara, and Ul'ianovsk cities) and rural settlements (Orel region and compact-type settlements in outlying rural areas of the Samara and Saratov regions). In the first study 73 per cent and in the second study 82 per cent of the respondents stated their nationality to be "Russian."6 All but a handful of the respondents (who had been displaced upon the territory of the Russian Fed- eration due to the conflict in Chechnia) had left the former republics, primarily Uzbekistan, Tajikistan, and Kazakstan, as well as Azerbaijan, Georgia, and Turkmenistan, between 1988 and 1999. The respondents were accessed through migrant associations, the migration service, and local academic contacts. In village locations and compact settlements, whole migrant communities were interviewed; in urban environments snowballing techniques were employed.

The regions chosen for study were areas popular for in-migration - the Volga region, as a whole, is one of the main regions for migrant settlement in the Russian Federation - but not regions with identified "tensions" arising from in-migration (such as Krasnodar territory in southern Russia). By 1 January 2000 the Volga region had received the second highest number of forced migrants and refugees of all Russia's economic regions - a total of $250,840 . .^{7}$ These figures do not include the large numbers of forced migrants and refugees who have not been registered. In both studies regions with comparable numbers of returnees but quite different migration environments were selected. In the 1994 study, Orel region had a positive attitude to the reception of migrants (even setting "targets" for reception) while the attractive nature of Ul'ianovsk city (given its reputation at the time of study for social stability and low cost of living) meant Ul'ianovsk was considerably more protectionist in its immigration policy. Of the regions included in the 1997-99 study, Saratov region pursued a relatively liberal migration policy and was fairly open to migrant arrival and resettlement, and there was active co-operation between the regional administration, the regional migration service, and migrant associations. However, an increasingly restrictive attitude was detected over the period of study. Samara region, in comparison, put greater restrictions on in-migration, the issue was not high on the agenda of the regional administration, and there was much less co-operation and dialogue between the migration service, relevant government departments, and migrant initiated groups.

\section{The "Russian Diaspora": Academic Models}

The Russian-speaking communities in the former republics have been the object of "diasporization." The newly independent Russian government sought to exercise Russia's great-power status in the "near abroad" through a discursive reconfiguration of the borders of post-Soviet Russia according to the geographical location of the Russian ethnos, rather than the current administrative borders of the Russian state. ${ }^{8}$ Indeed it was not only ethnic Russians who were declared to be the responsibility of the Russian government; all ethnic groups with a cultural and historical "link" to Russia were "diasporized" through a growing reference to 
the Russian-speaking minorities in the former republics as "compatriots" (sootechestvenniki). ${ }^{9}$ By configuring the relationship between Russia and the Russian communities in the "near abroad" in this way, the Russian government furnished itself with the right to "defend" Russian-speakers abroad - and thus to influence in the newly independent states - without undermining the civic - as opposed to ethnic - definition of the new Russian nation; the latter was crucial to the Yeltsin government in the first part of the 1990s as it distinguished "democrats" from "communists/nationalists." ${ }^{10}$ Although, in practice, Russian government rhetoric aimed at maintaining the Russian-speaking communities abroad as "ours" (including the passing of a law, Concerning the State Policy of the Russian Federation in Relation to its Compartriots Abroad, in March 1999) was tougher than either its real economic capabilities or its political will, ${ }^{11}$ nonetheless "diasporization" was important in that it positioned the Russian-speaking communities as an object of Russian state concern rather than as a policy matter for the newly independent states.

The process of "diasporization" of the Russian-speaking communities by the Russian state has led to an ambiguous and wide-ranging usage of the term "diaspora" in Russian media and political discourse. As Kolstø notes the "terminological anarchy" surrounding the diaspora debate demonstrates the political confusion on the issue, and the difficulty of defining who makes up this "diaspora" and its relationship to the Russian state. ${ }^{12}$ The term is frequently used in a general, all-encompassing manner with no critical analysis of what constitutes this diaspora. As Kosmarskaia comments, academics, politicians, and journalists have tended to use "diaspora" simply as a synonym or descriptive label for all the Russian-speaking populations in the newly independent states. ${ }^{13}$ Engaging with wider global debates, however, Russian academic literatures have sought to refine the use of the term "diaspora" and to critically evaluate its applicability, both in general conceptual terms, and with relation to the Russian speaking communities. ${ }^{14}$

No amount of political rhetoric, however, can make the Russians in the former republics "fit," subjectively, a classic diaspora model. Russian communities vary between, and even within, the former republics by socio-economic origin, length of time in the republic, degree of integration into the host community, and orientation towards return to Russia. While Anthias is surely right to criticize classificatory models of diaspora that ignore class, gender, and other differences within "diaspora," 15 in Russia even the assumption of common ethnicity, which lies at the core of understandings of "diaspora," is problematic. During the Soviet period, for example, although Russians formed the nucleus of settler communities in the other republics, their ethnic make-up depended heavily upon the region of settlement and always included Ukrainians and Belarusians alongside the Russians in the core group. ${ }^{16}$ The identity of the Russian-speaking communities was primarily defined in sociocultural rather than ethnic terms, therefore, and the connection to the "homeland" expressed in their economic and political placement within All-Union structures controlled from Moscow, rather than in any longing for "return." 17 In current debates within Russia, for example, liberal politicians, academics, and journalists avoid the term "ethnic Russians" when referring to the "diaspora" in an attempt to dilute the high degree of politicization of diaspora discourse and to counter the tendency among the nationalist camp to "over-ethnicize" the term. ${ }^{18}$

Secondly, although it is undoubtedly true that a greater awareness of themselves as "Russians" was experienced by the Russian-speaking communities in the former republics as a result of the "nationalizing nationalisms" of their host countries, ${ }^{19}$ the degree of that awareness was dependent not only on the policies of individual newly independent states, but also on the form of settlement that had developed in particular regions whilst under imperial Russian and then Soviet rule (size, ethnic composition, history of migration to the region), the socio-economic position of the settlers within each society, and the degree of cultural cleavage with the indigenous community. ${ }^{20}$ This degree of differentiation, as Graham Smith observes, meant that the Russians showed little sense of transnational solidarity linking their diasporic communities, either symbolically or through established social networks. Even within any Soviet successor state, Russian minorities displayed a weak sense of communal identity and thus a low level of collective action. ${ }^{21}$

The potential for the gradual development of a "communal identity" and ultimately a Russian "diaspora" community in the Soviet successor states is hotly disputed in Russia. Kudriavtsev claims that it is unlikely that a Russian diaspora will evolve and come to play an important role in the former republics precisely because it lacks any common ethnicity. Boronin goes still further, arguing that the shift from a "colonialist-paternalistic" mentality to that of a "persecuted minority" will push the Russian "diaspora," in time, into self-liquidation. ${ }^{22}$ Kosmarskaia argues, however, that while one cannot currently talk of "a diaspora" as such, the conditions for "diasporization" are in place and thus Russia currently has a "proto-diaspora." 23 This "emergent" diaspora is seen to differ from "traditional" historical diasporas - or those forming on the basis of migrant communities in the West - in that it takes a loose, fluid form based on informal friendship, professional, or family ties and lacks a mono-ethnic basis. Such "diasporization" is viewed as an alternative to the two, often promoted, solutions to the 
current situation of the Russian-speaking communities in the former republics - migration or assimilation. ${ }^{24}$ If this process were to take place, Lebedeva suggests it might coalesce around a number of key social institutions within the former republics and would act as a positive deterrent to further return migration. ${ }^{25}$

Thirdly, and for the purposes of this paper most significantly, in its strictest sense a diaspora refers to a people deprived of, or driven out of, its homeland, ${ }^{26}$ yet the Russian population in the "near abroad" has its ethnic "homeland" adjacent and apparently open for "compatriots" to return home at any time. ${ }^{27}$ While some, non-Russian, ethnic groups settled in the former republics following forcible deportations under Stalin, the majority of Russians resident in the former republics in 1991 arrived there through migratory processes encouraged as a means of securing the continually expanding borders of the Russian Empire. ${ }^{28}$ The peculiar, overland, formation of the Russian Empire marks out the "Russian diaspora" even from other colonizers "gone native." In the Russian case, as Rogers Brubaker notes, the original migration from core to periphery involved no crossing of state borders and thus migration was not only legally and politically defined as internal migration but was psychologically experienced as such. ${ }^{29}$ Thus, the migration of Russians to the outer edges of the Empire, according to Melvin, served to strengthen the colonial state and its institutions rather than to develop a distinct Russian ethnic and national identity and, in the Soviet period, although the boundaries of most ethnic and national communities became more rigid, "the margins of the Russian community retained a high degree of plasticity." 30 The contiguous nature of homeland and hostland, and their common statehood for a significant period of time, seriously disrupts the classic relationship between diaspora and "homeland"; for Russian-speaking communities in the former republics, a diasporic relationship to Russia "as homeland" was rarely experienced and, in the last century, frequently displaced onto "Soviet" identity.

Finally, diaspora status for Russians in the former Soviet republics is associated not with transnational movement, but with lack of movement; what moved in 1991 were the borders of the Soviet "homeland," not specific ethnic communities. This is not a unique occurrence. Robin Cohen, for example, classifies the Russians in the Soviet successor states as a "stranded minority," akin to Hungarians "stranded" across a number of other European countries upon the break-up of the Austro-Hungarian empire, whilst Emil Payin calls them an "imperial minority." ${ }^{11}$ In a similar fashion, David Laitin refers to ethnic minorities who become a diaspora as a result of boundary shifts as "beached" diasporas, ${ }^{32}$ whilst Brubaker refers to them as "accidental' diasporas." 33 On the same grounds - that the "diaspora" was a result of the collapse of empire rather than flight from the homeland - Graham Smith refers to the Russian "diaspora" as "borderland Russians," suggesting thereby that they are bound together only by their similar geographical location vis-à-vis the homeland - Russia - rather than any common identity. ${ }^{34}$

Transnational movement - going somewhere that is not "home" - is surely as central to diasporic identity as the concept of "homeland." The transnational migration actually experienced by Russian-speaking communities since 1991, however, is not away from Russia as "homeland" but back to "the homeland." In the case of Russian returnees from the former Soviet republics, this migration experience and the experience of the "homeland" when it is confronted upon return often results in a "misrecognition" of Russia; Russia is reconfigured as the "other" against which some form of diasporic identity is forged after return. In the empirical section of the paper, the process of identity formation of this "diaspora in diaspora" in the course of everyday experience of, and engagement with, the homeland are explored, as well as the ambiguities and limitations inherent in such an identity.

\section{Confronting "Homeland," Creating "Home": Real Lives}

The "homeland" is confronted by Russian returnees not once - as they cross the often transparent border to Russia - but repeatedly. "Homeland" is confronted firstly in its imagined form, appearing as a narrative among returnees of their life "there," in the former republics. It is confronted again, and on a daily basis, in the experience of "return" as returnees negotiate for status, employment, and housing and attempt to reconstruct "home" on Russian soil. ${ }^{35}$ The forms of this confrontation, and their implications for postmigration identity formation among returnee Russians, are considered below.

\section{Narratives of Life "There"}

The lack of a distinct diasporic identity amongst the Russian communities whilst resident in the other republics of the Soviet Union is supported by evidence from respondents' testimonies concerning their lives "there." The relationship of the returnees to the former republic was grounded, at least partially, in imperial consciousness. Respondents describe how they, their parents, or grandparents were sent out to the borderlands from the "centre" - Russia - to raise the economic and social level of the other republics as part of Soviet modernization drives. In this sense Russians in the non-Russian republics did not self-identify as "Russians" (a significant minority were not ethnic Russians) but socially and 
culturally as the "brightest and best," the chosen ones sent to bring cultural enlightenment and economic improvement to the "backward" parts of the Soviet Union. In narratives of life "there," this sense of superiority is expressed through self-identification as skilled, responsible, and conscientious workers, in contrast to representatives of the titular nationalities in the former republics who are seen as "loving management positions," of being capable of working only in commerce and thus being incapable of doing real work, i.e., producing:

Who worked? Only the Russians worked. They [those of the titular nationality] are not capable of anything. Only to be shopkeepers or work in cafes ... to water down the vodka. They are masters at short-changing ... but physical work ... that's not for them. -43 , Orel, $1994^{36}$

However, alongside such expressions of superiority, respondents articulated an admiration for the multinational state in which they lived and appreciation for the people, culture, and traditions of the former republic:

... you know they are so hospitable, generous, such sincere, rich people, we have probably learnt a lot from them, a great deal. I do not regret that I lived there, and was born there - this feeling of love for these people, simply this love for my homeland (rodina), it will always remain with me. - 53, Samara, 1999

Narratives of life "there" are grounded in a sense of the security, safeness, and completeness of life, based upon well-established networks, connections, and roots, which had been built up often over generations. In this sense the former republic is quite explicitly the land of their kin, their people (rod-ina). Respondents narrate how they, or their ancestors before them, were born in the former republic. They talk of growing up, getting married, and having children there. Their work, their flats and summer houses (dachas) are located there. These latter articulations indicate that not only did the former republics constitute the respondents' "homeland" but also where they were "at home" (doma).

The complexity of the relationship in relation to the former republic is also evident in the peculiar distortion of us/them, here/there boundaries found amongst returnee respondents. Russian returnees frequently talk about "at home there [the former republic]" ("u nas tam"), and "them here [Russia]" ("oni-tut"). Although it is impossible to list all articulations of this (it is a general speech pattern) the following statements make clear the impossibility of assuming the presence of even the fundamentals of
Russian identity: common language and shared home prior to the return "home."

Our Tajiks are very hospitable, our republic is called little Switzerland, it is very beautiful. — 9, Orel, 1994

... we don't even understand the Russians. When we arrived the first time, we could not understand the Russians, how they speak, the language. We could not understand. They don't understand us, and we them. - 31, Orel, 1994

The absence of remembered desires to "return" home or feelings of being separated ("in diaspora") from one's "homeland" are conspicuous and suggests that, for Russian returnees, the process of "returning" to Russia is an experience fraught with confrontation and contestation rather than a smooth journey "home."

\section{Migration Decisions: Leaving Home or Going Home?}

Despite their lack of diasporic identity, migration back to Russia became a common response among the Russianspeaking communities to the changing environment in the former Soviet republics from the late 1980s. A growing sense of "ethnic discomfort" was articulated by respondents through reference to the disruption of the security of everyday life, which had made this place "home." Respondents felt victims of discrimination on the basis of language and nationality in the spheres of employment and education. Daily activities, such as shopping, using public transport, or walking down the street were no longer "safe" and unproblematic. Many respondents spoke of the verbal abuse they received on the grounds of their ethnicity and of being told to "return" to "their Russia":

Your homeland (rodina) is Russia - you are Russian - go back to your Russia. — 42, Saratov, 1999

The disruption of everyday life was accompanied often by feelings of extreme danger and insecurity, and in some cases respondents had been caught up in violent ethnic conflict. For a minority of respondents this experience - a "borderland experience" - not only made them more acutely aware of their "Russianness" but gave rise to a defensively aggressive sense of that nationality. As one returnee from Moldova noted:

I am a Russian (russkii), not a Russian citizen (rossiianin) because ... I lived on the border.... On the border of the division of nations. Russians who live here don't understand that.... Only now are they beginning to sense that other nationalities exist, they have not understood this yet.... I understood this a long 
time ago...and thanks to this, there on the national periphery, I became more Russian than the Russians here. - 136, Ul'ianovsk, 1994

Such experiences of ethnic discomfort meant that the adjacent "historical" homeland - Russia - now presented itself as the logical solution to the displacement felt; migration to Russia was for many the only possible response.

\section{Encounters with the "Homeland": No Longer an Object of State Concern}

The process of "diasporization" of the Russian-speaking communities in the "near abroad" by the Russian state is important for understanding returnees' encounters with the homeland. While resident in the former republics, the Russians had been an object of considerable state concern. For a minority of respondents migration to Russia was perceived, therefore, as a return to an ethnic homeland:

We are Russian (russkie), we have come to our Russian brothers, we have not just moved anywhere, we have come to our native Russia. — 35, Saratov, 1999

Upon return, however, most returnees feel that state concern had evaporated. The most common response to this among respondents was a feeling of "hurt" that while they had "done their duty" for Russia, the Russian state considered them "redundant" and was indifferent to their plight:

Where did the Russians in Kazakstan appear from? They came from Russia. Then it was in the interests of Russia to send them there - so they would open up a new land.... But now, when we want to return, after three or four generations, because we are being driven out - they will not take us here. We are redundant (my ne nuzhni) - 36, Saratov, 1999

The absence of the state is tangible; the actual journeys made by migrants and the location of places for settlement are conducted with the assistance only of family or friendship networks. This reflects the reluctance of the state to frame these journeys as a repatriation movement rather than as a collection of individual experiences. ${ }^{37}$ State concern, it appears, is located "there," not "here."

This is not to suggest that the state, at the federal level, has made no provision for returnees. In February 1993 the Russian Federation laws On Refugees and On Forced Migrants were introduced and distinguished between a "forced migrant," who was a citizen of the Russian Federation, and a "refugee," who was not. Thus, from the outset, legislative frameworks set the Russian returnees apart, and the category of "forced migrant" seemed to be an acknowledgement by the Russian state of a special status. The Federal Migration Service (FMS) of the Russian Federation was established in June 1992 and mandated to "protect the rights of refugees and forced migrants and help in their resettlement." Federal and regional level legislation has been introduced to further this aim, but actual implementation has been limited. Furthermore, the role of the Federal Migration Service, and the direction of policy towards the returning communities in general, gradually shifted from providing protection and assistance for migrant resettlement to prioritizing control and management of migration movements. The respondents' testimonies reveal both a concrete lack of state provision, and a feeling of psychological distance from the service, which is not seen as central to "their" resettlement. Although some help is received, migrants frequently mention that forced migrant status has proved to be little more than "a piece of paper" and does not secure any concrete help. ${ }^{38}$ There is a distinct lack of faith in the migration service which centres around the claim that the employees of the service cannot, and do not want to, understand what has happened to the migrants and are unwilling to help:

At the migration service it is not "our" people who sit there, but "locals." And "locals" do not understand our problems at all.

—35, Saratov, 1999

The migration service itself has long ago given up on us. They say, "Look, you are already here, you have citizenship, get on with it!" - 41, Saratov, 1999

The perception of state abandonment is felt in relation to both regional and federal administrations:

I have the feeling that they [the local administration] don't consider us at all. I don't know whether it is just this local administration [Samara] that has this attitude. I don't know if other migrants live better, maybe there is somewhere, where they live worse than us. But in principle you do not expect help from anyone, you have to survive on your own. It is evident they have forgotten that we exist in Moscow. It has become almost insulting. - 46, Samara, 1999

Thus, although "registered" forced migrants hold Russian citizenship and are offered some minimal state assistance, the former is taken for granted by Russian returnees while the latter is experienced as derisory. Thus "returnees" do not feel welcomed by the Russian state and turn to other resources - selves, family and friendship networks - in order to recreate what constitutes "home" and secure their inclusion in Russian society. 
One alternative to self-reliance has been participation in migrant initiatives such as "compact settlements" and "migrant associations." The idea of "compact settlements" was first promoted by a Russian federal level non-governmental association, the Coordinating Council of Aid for Refugees and Forced Migrants (CCARFM), as a "realistic solution" to the problems of housing, employment, and adaptation faced upon return, and as providing a necessary feeling of security, community and social inclusion. ${ }^{39}$ The attitude of the Federal Migration Service to the idea of compact settlements fluctuated over time, alternating between support for the idea and limited financial and material help, to open hostility and opposition in cases of individual compact settlements. Many governmental and non-governmental experts held reservations about the future of compact settlements, one concern being that they might encourage the long-term social exclusion of forced migrants. There has been widespread recognition that settlements should only be encouraged where they have viable locations near existing urban settlements. ${ }^{40}$ On the territory of Saratov and Samara regions, great difficulties have been faced in the establishment of compact settlements. Most of the settlements received initial help from the migration service and local administration. However, a subsequent lack of resources, the failure of the settlements' enterprises, conflicts within the migrant groups, and the unsuitability of the location of the settlement have meant that the majority are now struggling to survive.

Attitudes to this type of settlement amongst returnees reflect both the post-hoc diasporic identity that develops among returnees, and also their conscious desire to recreate "home" in their "new" homeland. Thus, compact settlements are perceived as providing housing and employment on site, but also a beneficial environment upon arrival to facilitate inclusion because they bring together "similar" people to themselves (that is, other migrants):

I would be very pleased, if it was all migrants - let's say from Tajikistan, Kazakstan - all the former republics. Because we are from "one and the same plate." Everything we had was the same. We would be very good together. We understand each other. They ["local" Russians] do not understand us.... they have their culture, we have our culture. — 35, Saratov, 1999

On the other hand, compact settlements are also perceived as working to isolate returnees in rural areas where their professional skills cannot be applied and their families find it difficult to integrate. Moreover, this self-containment might generate exclusion from wider society and thus inhibit adaptation: ${ }^{41}$
I think it is better to live together with the local population ... it is impossible to be separate, we must integrate faster. In order to integrate it is absolutely necessary to live with the Russians (rossiiane). If we acquire citizenship, we want to take part in the affairs of Russia. We will also feel ourselves to be rossiiane. Therefore we must mix with them. Compact settlements - I do not consider they are that good an idea. - 21, Saratov, 1999

Those migrants who have had experience of living on a compact settlement, or who presently live in such a settlement, are concerned mainly with the realities of making the settlement work. Nevertheless, they have already invested a great deal of physical and emotional energy into the settlement and feel a sense of community strong enough to deter them from abandoning hope in its eventual success:

We have to persevere, the place here is not bad, it is beautiful, we hope to achieve something here. The children like it, and we have already become accustomed, we know the place, it already seems a shame to leave. And here living on the hillside, we have our clan, we ... are all newcomers (priezhie), we have our community (obshchina), we have our own outlook and views, a lot of us do not want to leave the hillside, we already want to build our settlement here. — 59, Samara, 1999

While the Russian-speaking communities in the former republics have failed largely to generate their own community organizations, returnees have developed migrant associations rapidly which help fill the gap left by the lack of government provision. In Saratov and Samara regions a number of associations have been established, ${ }^{42}$ although many respondents either had not heard of them or did not know what they did. Others identified migrant associations as yet another "official" structure in which one should have little faith as a source of help. Migrants who had contact with the associations, or were actually involved in their operation, had a different perception of the role and importance of such bodies, however. They were seen clearly as a response to state indifference, and as a source of real potential help:

... if the government does not care, then we must come together in a group, what other way is there? - 37, Saratov, 1999

Moreover, although a formal structure, migrant associations were considered, unlike official government structures, to approach migrants with understanding and empathy. The reason for this is that the associations are run by migrants, who both have had a similar experience of displacement and may have come from the individual's previous "homeland": 
She [the head of one association] always listens to you when you go there, she will always give you advice. She is our fellow countrywoman (zemliachka), also from Uzbekistan. She knows what it is like, she has gone through it herself, so it is easier for her to understand. — 41, Saratov, 1999

If people have gone through it themselves, they understand that it is very difficult. All the people try to support you with warm words, to provide help in some way, to do something. In the migration service it is more difficult, you go there and it is like a "deaf wall," a wall that doesn't understand, and people who do not understand - that a person has come with nothing, has to start again, and that adaptation is very difficult. Here [in the migrant association] it is easier, you can always run to the association with any question. — 50, Samara, 1999

To those migrants who are included in the sphere of activity of the migrant associations feelings of group identity are generated, which draw upon the common experience of both residence in, and displacement from, a former republic. Both the compact settlements and the migrant associations create spaces where feelings of common identity are discovered and fostered. However, there is great diversity of interest and identity amongst the migrant community and many returnees do not consider the associations as integral to the process of resettlement. For them resettlement remains an individual or family centred process, and the reconstruction of "home" and "homeland" one of personal negotiation.

\section{"Other Russians": Local Encounters with "Homeland"}

The process of resettlement fosters a sense of "difference" among Russians returning to the Russian Federation; this difference is grounded clearly in the experience of life "there," but is framed in terms of sites of confrontation with the "homeland" and, in particular, in opposition to "local" Russians. The feelings of superiority rooted in imperial consciousness, which were expressed vis-à-vis the titular population in the former republic, are also voiced upon "return" and in relation to the local population. Returnees consistently described local Russians as: rude, disrespectful (especially of their elders), linguistically impoverished, drunken, and lazy:

... by nationality I am Russian but I consider myself Soviet.... I don't consider myself a rossiianka ... the locals ... they are pure rossiiskie people ... a Russian [russkii] it seems to me should be a good, kind, considerate, hospitable person, a cultured, educated person, but a rossiiskii - that is about getting drunk, not going to work, all that...all the bad characteristics. — 119, Orel, 1994
... the cultural level in Russia is very low, relationships between people are completely different, ... those who have arrived, they are highly educated and highly specialized. They are very hardworking, and come with the desire to work ... it is highly qualified, cultured, intellectual, well brought up people who have arrived. — 53, Samara, 1999

Although the returnees do think of themselves as ethnically "Russian," they feel their Russianness to be challenged by the local population. Returnees claimed that they were labelled as outsiders by locals who referred to them as: "newcomers" or "strangers" (priezhie), "immigrants" (immigranty), "emigrants [sic]" (emigranty), "migrants" (migranty and pereselentsy), "refugees" or, according to the republic they have come from, "Kazaks," "Kirghiz," etc. This, returnees said, meant that they were effectively excluded from the common ethnic and civic community:

The same Russians don't accept us as Russians.... We have no rights at all here. - 1, Orel, 1994

It is us who are strangers, we who have arrived. Yes, we are Russians (russkie), but we are not perceived as Russians. We are strangers, and I think that our children, who have come with us, they will also be strangers. - 45, Saratov, 1999

I am Russian (russkaia), my husband is Russian (russkii), but everyone treats me as a Kazak (Kazashka) at work, if you are from Kazakstan [to them] it means you are a Kazak.

-49, Samara, 1999)

The returnees also complained that general economic problems were blamed on increased competition generated by their arrival:

... we are not treated well, all the time we are called "blacks" ... "foreigners"... They don't like us. Many say "you have taken our flats." Very many complain "you have swarmed down on us, taken our jobs, our flats, because of you, life is tough here now...." - 178, Ul'ianovsk, 1994

$\ldots$ it seems to them that we take their work, their money. When a country "fills up," there are soon difficulties, therefore people already look at you in a different way. We are like competitors for "life." - 36, Saratov, 1999

Encounters with the homeland at the local level thus engender a sense among returnees that though they may be Russians, they are "other" Russians:

Although we are Russians (russkie), we are not the same kind of Russians that live here. - 1, Orel, 1994 
This essence of this "otherness" lies at the heart of the "diaspora-in-diaspora" identity; returnees differentiate themselves from local Russians by ascribing to "self" those positive characteristics attributed to the peoples of the republic of former residence. Many respondents openly acknowledged a kind of "hybrid" identity, saying that they had assimilated much from the peoples they had lived with:

We arrived like that ... the East is like that. We were taught like that there. The Uzbeks, the Tajiks they are all like that. For them the main thing is the family ... that is why we have got more in common with the [other] newcomers (priezhie) than with the locals. There is a big difference between us and them. -20 , Orel, 1994

... here we are all newcomers (priezhie). We are all close to each other in spirit. Everyone is from Central Asia here, I came from there. We have our own way of life, although I am Russian (russkaia), my way of life is more similar to an Eastern woman's. Therefore we have found a common language. Newcomers, no-one loves them anywhere. Here, we are all together, we are all a group...we can communicate, we have a great deal in common, our way of life, for example. We even have the same dishes, if you go to that extent. We prepare dishes in the same way. It means a great deal. And to have left there, to have lost everything, left everything.... such little things give you joy. We have common recollections, a common outlook. It is something important for us. — 27, Saratov, 1999

A sense of common experience and common identity thus appears to emerge among returnees as a product of the daily encounter and confrontation with the "historical homeland" after return to Russia.

\section{Revisiting the Concept of "Diaspora": Constructions of "Home" and "Homeland"}

Evidence of a common identity amongst returnees is not proof of "diasporic" identity. The latter claim, once again, requires evidence of the centrality of the old (former republic) homeland to the sense of community among returnees. The articulation of "homeland" in returnees' narratives, however, suggests that although "homeland" is important to returnees' identity, it is not a single concept, but is fluid and under constant re-formation throughout the process of reconstructing "home" in Russia.

The understanding of "homeland" (rodina) in the narratives of returnees is complex. Around two-thirds of respondents in Orel region expressly said they did not consider their migration to Russia to be a return to the rodina. The majority of respondents from Saratov and Samara regions, when they spoke of their rodina also placed it "there" (in the former republic). This is, in many ways, logical. Linguistically, the term rodina fixes homeland as the "place of birth," and many respondents identified their rodina as "there," where they were born:

I was born there, lived there. Of course it is hard. You yearn ... for your homeland. And that homeland is there, there where you were born, in spirit you never leave. — 189, Orel, 1994

Rodina, is where you are born, we were born in Tajikistan, our homeland is there. - 11, Saratov, 1997

For other respondents homeland was linked to the former USSR as a whole and the latter's disappearance was thus experienced as bereavement. The sense of loss is as much for the security of the "past" - of employment, housing, established friends, and community - as for any consciously multi-ethnic society, of course. The insecurity and uncertainty faced upon return to Russia thus generate a bitter sense of loss of belonging:

We haven't got one [rodina]. We are aliens there and here we are aliens ... the children were born there in Uzbekistan. We haven't got a homeland! - 125, Orel, 1994

For others, however, although they share a sense of having "no homeland," their focus is the "present" process of reconstructing "home." By rebuilding one's "home" signifying the security of housing and employment, the establishment of family and friends, security, and a future for their children - they establish the foundations for a future "homeland" on the territory of Russia. The process is not one of return to a familiar ethnic community, but a process of "becoming" or "rooting":

There I am a stranger, and here I am still not myself. That is, I am between the sky and earth. I am not there, or here...if everything were settled, if there were housing and work, then I could say I would never leave here - it would be my "home."

-43, Saratov, 1999

My rodina is there, where I was born, where my friends are. But I think Russia has to become my "home." If there is housing, then Russia will become homeland and home, because our children will be here. Our children will have children, and there will be grandchildren. Therefore I will consider that Russia - it is my home. - 35, Saratov, 1999

These narratives describe a process of "recreation" and transferral. There is a clear acceptance that the period of rodina being "there" is over in a physical, lived sense. Re- 
spondents rarely envisaged return as a real possibility, although the memory of homeland "there" remained potent. The first step was to recreate "home" in Russia; if they managed this successfully, it might become "homeland" for future generations:

I cannot say that I exactly feel at home. But, I feel calm, simply calm. It is already the children, grandchildren, this will be their rodina in time, when it has all settled down. —39, Saratov, 1999

Statements made by returnees concerning their "homeland" are complex and contradictory. While theorists of the postmodern would suggest that the contemporary world of diaspora, mass population movement, and transcultural flows naturally problematize the notion of homeland, ${ }^{43}$ this does not fully explain the sentiments expressed by respondents. For Russian-speaking returnees, there was no problem of envisaging what constituted a homeland; it was clearly symbolized by "where I was born," "where the children were born," and "where my parents are buried." The problem was rather a sudden disembodiment of that homeland. The "imagined community" (Russia) had been severed from the physical homeland (former republic) leaving individuals and communities displaced. To resolve this displacement, many Russian-speakers in the former Soviet republics took the migration option. Their experience of "return" to Russia, however, was not one of "going home" to an ethnic homeland, but of recognizing, post-factum, a diasporic identity and then seeking to re-root themselves through actively reconstructing "home."

\section{Conclusion}

The peculiar process of settlement of Russians in the former Soviet republics and the process of their objective, but not subjective, "diasporization" in the post-1991 period problematize the application of a classic "diaspora" model to the experience of these stranded, imperial minorities. In particular the central relationship between diaspora and "homeland" is disrupted. Until the late 1980s, generations of Russian-speakers in the former Soviet republics envisaged no split between physical homeland as where they lived, where their children were born, and where their parents had died, and homeland as "imagined community." The Soviet homeland (sovetskaia rodina) embodied both. The rise in ethnic tension through the 1980s and the sudden collapse of the Soviet Union at the end of 1991, however, severed the two, leaving the Russian communities displaced.

This paper has explored one resolution of this displacement: migration, or rather return to "historical homeland." It has suggested that the experience of encountering Russia as homeland, however, does not necessarily bring those in diaspora "home," but often engenders a sense of "otherness" and exclusion. What appears to emerge is a sense of common identity among Russians from the former republics upon return, which had not been present while in diaspora; a "diaspora-in-diaspora" identity? The possibility that diasporic identity may be stronger amongst those forced to "return" to their historical "rodina" than amongst those who remain "there" has indeed been suggested by Gradirovskii. ${ }^{44}$ To talk of such an identity, however, surely stretches the concept of "diaspora" too far. Rather than make claims for such an identity, therefore, the paper has suggested that it might be useful to unpack the notion of "homeland" into "home" and "land." This would disavow the primacy of a primordial connection between ethnos and territory embodied in the notion of "homeland." It suggests, rather, that homelands "become" through the siting of an individual's "home" (kin, family, past, present, future, job, house). What returnee experience reveals is that everyday encounters and confrontations with the "ethnic homeland" engender both a diasporic longing for the "homeland" left behind whilst at the same time siting individuals and families in a space which they will make "home" for themselves and "homeland" for their children.

\section{Notes}

1. There were 25.3 million ethnic Russians living in Soviet republics other than the Russian Federation according to the last Soviet census, conducted in 1989. In addition there were approximately 11 million members of other ethnic groups whose primary cultural affinity is Russia and who are often subsumed into the "Russian" diaspora as "russophones" or the "Russian-speaking population."

2. See: Ian Bremmer, "The Politics of Ethnicity: Russians in the New Ukraine," Europe-Asia Studies 46, no. 2 (1994): 261-83; Tim Heleniak, "Migration of the Russian Diaspora after the Break-up of the Soviet Union," Journal of International Affairs 57, no. 2 (2004): 99-117; Pal Kolstø, Russians in the Former Soviet Republics (London: Hurst, 1995); Neil Melvin, "Forging the New Russian Nation" (Discussion Paper 50, Royal Institute of International Affairs, London, 1994); Neil Melvin, Russians beyond Russia's Borders (London: Pinter/Royal Institute of International Affairs, 1995); Vladimir Shlapentokh, Munir Sendich, and Emil Payin, eds., The New Russian Diaspora: Russian Minorities in the Former Soviet Republics (New York and London: M.E. Sharpe, 1994); Jeff Chinn and Robert Kaiser, Russians as the New Minority. Ethnicity and Nationalism in the Soviet Successor States (Boulder: Westview Press, 1996); Graham Smith, "Transnational Politics and the Politics of the Russian Diaspora," Ethnic and Racial Studies 22, no. 3 (1999): 500-23; Graham Smith, The Post-Soviet States (London: Arnold, 1999); Charles King and Neil Melvin, eds., $\mathrm{Na}$ tions Abroad: Diaspora Politics and International Relations in 
the Former Soviet Union (Boulder: Westview Press, 1998); Charles King and Neil Melvin, "Diaspora Politics: Ethnic Linkages, Foreign Policy and Security in Eurasia," International Security, 24, no. 3 (1999/2000): 108-38; David Laitin, Identity Formation: The Russian-Speaking Populations in the Near Abroad (Ithaca: Cornell University Press, 1998); Edwin Poppe and Louk Hagendoorn, "Types of Identification among Russians in the 'Near Abroad." Europe-Asia Studies 53, no. 1 (2001): 57-71.

3. Russia began to receive a net inflow of migrants from the Soviet republics from the late 1970s but this gradual "decolonization" was replaced by repeated waves of "refugees" and "forced migrants" during the late 1980s and first half of the 1990s as ethnic conflict and economic collapse became part of the everyday realities of life in the former Soviet republics. The registration of returnees by the Federal Migration Service of the Russian Federation was begun in July 1992. By the end of 2002, approximately 1.5 million refugees and "Russian-speaking forced migrants" (russkoiazychnie vynuzhdennie pereselentsy) had been registered in the Russian Federation; see Goskomstat, Regiony Rossii, Statisticheskii sbornik, Vol. 2 (Moscow: Goskomstat, 1998), 68; Goskomstat, Statisticheskii biulleten. Chislennost' I migratsiia naseleniia rossiiskoi federatsii v 1999 godu (Moscow: Goskomstat, 2000), 113; Goskomstat Demograficheskii ezhegodnik rossii (Moscow: Goskomstat, 2002), 128. Many more people have been temporarily or permanently displaced in the former Soviet Union, however, and it is estimated that the actual number in Russia is between 8 and 10 million; see International Organization of Migration, "Management of Migration in the CIS Countries" (IOM Open Forum Information Series, 3, 2002).

4. This fieldwork was conducted by Hilary Polkington as part of a wider project supported financially by the Economic and Social Research Council under the Research Grant scheme (Award R000221306 "Going Home: A Socio-cultural study of Russian-speaking forced migrants”, June 1994-August 1995).

5. This fieldwork was conducted by Moya Flynn as part of her research for her doctoral thesis, entitled "Global Frameworks, Local Realities: Migrant Resettlement in the Russian Federation" (University of Birmingham, 2001).

6. The lower proportion of "Russians" in the first study results primarily from a large number of Tatar returnees choosing to settle in Ul'ianovsk oblast', which has a significant Tatar minority.

7. Within the Volga region, Samara received the highest number of forced migrants and refugees over the period 1992 to January 2000, a total of 69,983. Saratov region received the second largest number of forced migrants and refugees, a total of 54,625 . Ul'ianovsk region received 12,159 forced migrants and refugees over the same period and Orel region, 13, 610 (Federal Migration Service Statistics, unpublished data, 1998); Goskomstat Rossii, Regiony Rossii, 68; Goskomstat Statisticheskii biulleten, 115.

8. Hilary Pilkington, Migration, Displacement and Identity in Post-Soviet Russia (London and New York: Routledge, 1998), 25.
9. Ibid., 26; Neil Melvin, "The Russians: Diaspora and the End of Empire," in King and Melvin, 39.

10. Pilkington, 56-57; Melvin, "The Russian Diaspora and the End of Empire," 47.

11. Igor Zevelev, "Russia and the Russian Diasporas," Post-Soviet Affairs 12, no. 3 (1996): 265-84; Melvin, "The Russian Diaspora and the End of Empire," 48.

12. Kolstø, 262-63.

13. Natalya Kosmarskaia, "Ia nikuda ne khochu uezhat', zhizhn' v post-sovetskoi Kirgizii glazami russkikh," Vestnik Evrazii 1-2 (1998): 76.

14. Aleksander Militarev, "O soderzhanii termina 'diaspora' (k razrabotke definitsii)," Diaspori 1 (1999): 24-33 (Militarev addresses the usage of the term; however, he does not use it at all in relation to the Russian-speaking communities); Sergei Gradirovskii, "Rossiia i postsovetski gosudarstva: iskushenie diasporal'noi politikoi," Diaspori 2-3 (1999): 40-58; Natalya Lebedeva, Novaia russkaia diaspora. Sotsial'no-psichologicheskii analiz (Moscow: 1998); Kosmarskaia, "Ia nikuda ne khochu uezhat'," 76-100; Natalya Kosmarskaia, "Russkie diaspory: Politicheskie mifologii i realii massogo soznaniia," Diaspory 2 (2002): 110-56; Natalya Kosmarskaia, "Russkie diaspory: Nauchnii diskurs I nizovie vospriatiia," Diaspory 4 (2003): 142-204; Natalya Kosmarskaia, "Russkoiaychnie blizhnego zarubezh'ia: diaspornii proekt protiv avtokhtonnogo," Diaspory 1 (2004): 148-84.

15. Floya Anthias, "Evaluating Diaspora: Beyond Ethnicity," Sociology 32, no. 3 (1998): 564.

16. Melvin, "The Russians: Diaspora and the End of Empire," 33.

17. Ibid. Empirical research confirms this lack of ethnic solidarity among diaspora communities and points to socio-cultural links as providing a possible common, diasporic identity: Gradirovskii, 3; Zevelev, 279; Viktor Kudriavtsev, "Lovushka integratsii,” Nezavisimaia Gazeta, June 25, 1996.

18. Kolst $\varnothing, 260$. The ethnicization of the Russian media debate on diaspora is evidenced by the frequent use of the ethnically exclusive terms "Russians" (russkie) or "ethnic Russians" (etnicheskie russkie) to refer to the Russian-speaking minorities in the former Soviet Union; see Pilkington, 25.

19. Rogers Brubaker, "Accidental Diasporas and External "homelands' in Central and Eastern Europe: Past and Present" (paper presented at the international conference "Diasporas: Transnational Identities and the Politics of the Homeland," University of California at Berkeley, November 12-13, 1999).

20. Melvin, "The Russians: Diaspora and the End of Empire," 48.

21. Smith, The Post-Soviet States, 78.

22. Kudriavtsev, 3; Voronin, cited in Kosmarskaia, "Ia nikuda ne khochu uezhat," 76.

23. Kosmarskaia, "Ia nikuda ne khochu uezhat'." In the article Kosmarskaia explores the possibility of the development of a Russian diaspora in the Kyrgyz Republic, by addressing the questions of how this would come about, who would constitute this "diaspora," and why it would be possible in the Kyrgyz Republic. 
24. Ibid. Also Natalya Kosmarskaia, "Khotiat li russkie v Rossiiu? (Sdvigi v migratsionnoi situatsii I polozhenii russkoiazichnogo naseleniia Kirgizii)," in V Dvizhenii dobrovol'nom I vyuzhdennom, Postsovetskie migratsii v Evrazii, ed. Anatoly Viatkin, Natalya Kosmarskaia, and Sergei Panarin (Moscow: Natalis, 1999), 207.

25. Lebedeva. This approach has been criticized by Kosmarskaia for ignoring the specifics of the post-Soviet case, where those individuals who decide to "stay" are unlikely to be involved in any type of official, socio-cultural organization; Kosmarskaia, "Ia nikuda ne khochu uezhat'."

26. William Safran, "Describing and Analyzing of Diaspora: An Attempt at Conceptual Cleansing" (paper presented at the international conference "Diasporas: Transnational Identities and the Politics of the Homeland," University of California at Berkeley, November 12-13, 1999).

27. Hilary Pilkington, "Going Home? The Implications of Forced Migration for National Identity Formation in Post-Soviet Russia," in The New Migration in Europe: Social Constructions and Social Realities, ed. K. Koser and H. Lutz (Basingstoke: Macmillan, 1998), 86.

28. Melvin, "The Russians: Diaspora and the End of Empire," 30. 29. Brubaker.

30. Melvin, "The Russians: Diaspora and the End of Empire," 28.

31. Robin Cohen, Global Diasporas: An Introduction (London: UCL Press, 1997), 191; Emil Payin, "The Disintegration of the Empire and the Fate of the "Imperial Minority" in Shlapentokh, Sendich, and Payin, 21-36.

32. Cited in Safran.

33. Brubaker.

34. Smith, The Post-Soviet States.

35. Numerous studies have been conducted which explore the different aspects of processes of resettlement and adaptation of Russian-speaking migrants on the territory of the Russian Federation: Pilkington, Migration, Displacement and Identity, and Moya Flynn, Migrant Resettlement in the Russian Federation: Reconstructing "Homes and "Homelands" (Anthem: London, 2004) explore the socio-cultural and socio-economic aspects of adaptation and the complex understandings of Russian migrant identity. Sociological studies by Cherviakov, Shapiro, and Sheregi (1991), Vitkovskaia (1993), Susokolov (1994) cited in Pilkington, Migration, Displacement and Identity, 25, look at issues of reception and adaptation of migrants in Russia alongside questions of migrant intention. Other studies concentrate specifically on the regional and locational aspects of migrant resettlement, and look at the impact of region and "type" of settlement (urban, rural), alongside factors including gender, education, employment, housing and political orientation, upon the success of migrant adaptation. See Zhanna Zaionchkovskaia, "Vozmmozhno li organizovat' pereselenie na Dal'nii Vostok," Migratsiia 3 (1997): 13-15; Galina Vitkovskaia, "Adaptatsiia vynuzhdennikh migrantov v raznikh tipakh poselenii v Rossii” in Migratsiia i urbanizatsiia $v$ SNG i Baltii v 1990s, ed. G. Vitkovskaia and Zh. Zaionchkovskaia (Moscow: Centre for the Study of Problems of Forced Migrants in the CIS, 1999): 199-240; Galina Vitkovskaiia, "Za kogo golosyut vynuzhdennie pereselentsy?" Migratsiia 3 (1997): 26-30; Elena Filippova "Adaptatsiia russkikh vynuzhdennikh migrantov iz novogo zarubezh'ia," in Vynuzhdennie migranty: Integratsiia I vozvrashchenie, ed. V. Tishkov (Moscow: Institute of Ethnology and Anthropology, RAS, 1997), 45-74. Vitkovskaiia completed a comprehensive study of migrant resettlement across the Russian Federation which looks at migration trends, regional resettlement patterns, urban and rural settlement, and the major factors affecting the resettlement process: Galina Vitkovskaia, Resettlement of "Refugees" and "Forced Migrants" in the Russian Federation (Geneva: International Organization of Migration, 1998). A regional study focuses upon the socio-psychological adaptation of Russian forced migrants and refugees in Saratov and Volgograd regions: Valentina Grishchenko, Russkie sredi Russkikh: Problemy adaptatsii vynuzhdennikh migrantov I bezhentsev iz stran blizhnego zarubezh'ia $v$ Rossii (Moscow: Institute of Ethnology and Anthropology, 1999).

36. In the interests of anonymity, respondents are referred to only by the identification number assigned them in the databases of biographical details conducted for each of the fieldwork studies, the region of their resettlement, and the year of interview.

37. This can be contrasted with repatriation programs that exist for Russian Jews returning to Israel, or ethnic German Russians returning to Germany.

38. This help is predominantly in the form of a small, one-off monetary payment or an interest-free, returnable loan for the construction, renovation, or purchase of housing. The 1994 study saw a pitiful level of state assistance; the payment had been received by 31 per cent of respondents in Orel and 14 per cent in Ul'ianovsk while the housing loan had been received by just one family who, coincidentally, were personal friends of the head of the regional migration service. In Samara and Saratov regions nineteen respondents (out of the total of sixty-two) had received the one-off payment while only six individuals had received the housing loan. In explaining the low take-up, the majority of respondents pointed to the difficulties of application, the bureaucracy involved, and the unrealistic possibility of returning the loan.

39. Lidiia Grafova, Elena Filipova, and Natalya Lebedeva, Compact Settlements of Forced Migrants on the Territory of Russia (unpublished report, Open Society Institute, New York, 1995).

40. In-depth studies by Filipova have looked at the concept of compact settlements, concentrating upon: their development in the Russian Federation; the problem with defining what constitutes a compact settlement; the advantages and disadvantages of this method of settlement for successful adaptation; governmental attitudes to compact settlements; and the importance of location and population constitution for the success of the settlements; see Elena Filippova, "Opit sozdaniia kompaktnikh poselenii migrantov v Rossii," in Tishkov, 75-88; Elena Filippova, "Obshchinno-kompaktnie poseleniia: 
uslobiia uspekha I prichini neudach," Prava Cheloveka 1 (1998): 6-11.

41. The perception amongst migrants across the Russian Federation that compact settlements can either provide a familiar environment where they are understood, or on the contrary, as leading to problems of isolation and exclusion from the local community, is referred to in the study by Filippova, "Obshchinno-kompaktnie poseleniia: usloviia uspekha I prichiny neudach."

42. During the period of the study there were three main organizations in the city of Saratov and one main organization in the city of Samara. Other smaller organizations existed on the territory of the regions. The associations in Saratov were at a more developed stage than in Samara region. This was mainly due to the liberal environment conducive for their development, but also could be seen as an indicator for the greater need for such associations in Saratov region.

43. Andrew Gupta and James Ferguson, "Beyond 'Culture': Space, Identity, and the Politics of Difference," Cultural Anthropology 7, no. 1 (1992): 10.

44. Gradirovskii, 44.

Hilary Pilkington is Professor of Sociology and Russian Studies and Director of the Centre for Russian and East European Studies at the University of Birmingham, UK. She has published widely on issues of Russian society and culture including, in the area of migration studies, Migration, Displacement and Identity in Post-Soviet Russia (London and New York: Routledge, 1998).

Moya Flynn is Lecturer in the Department of Central and East European Studies at the University of Glasgow, UK. She has published on issues concerning forced migration, diaspora, and identity in the former Soviet Union, including Migrant Resettlement in the Russian Federation: Reconstructing Homes and Homelands (London: Anthem, 2004).

(c) Hilary Pilkington and Moya Flynn, 2006. This open-access work is licensed under a Creative Commons Attribution-NonCommercial 4.0 International License, which permits use, reproduction and distribution in any medium for non-commercial purposes, provided the original author(s) are credited and the original publication in Refuge: Canada's Journal on Refugees is cited. 